V. Lozitsky, Dr Hab.

Taras Shevchenko National University of Kyiv, Kyiv

\title{
SPECTRAL INVESTIGATIONS OF MAGNETIC FIELDS AND THERMODYNAMIC CONDITIONS IN ACTIVE REGIONS ON THE SUN
}

The main results of studies of magnetic fields and thermodynamic conditions in active regions in the Sun obtained at the Astronomical Observatory of the Taras Shevchenko National University of Kyiv (AO KNU) during the last 10 years (2010-2019) are presented. The true diameter of the extremely small (spatially unresolved) magnetic flux tubes was estimated on a base of data from Hinode Space Observatory; this diameter was found to be within the range of $15-20 \mathrm{~km}$, which is much smaller than the spatial resolution limit of the largest solar telescopes to date $(\approx 60 \mathrm{~km})$. According to the observations made at $A O$ $K N U$, it was shown that there are three types of magnetic fields in a solar faculae: strong (kilogauss range) fields in small-scale flux tubes, areas of weak and moderate background fields of regular polarity, and areas of sub-telescopic fields of mixed polarity. The magnetic flux of mixed polarity exceeds the absolute flux of the entire field of regular polarity by at least 2 times. In the sunspot umbra observed at GST of AO KNU and ATsU-5 of GAO NASU, thin spectral effects of Zeeman splitting were found, which indicate presence of very strong magnetic fields at least of 5,8 kG. The polarity of the magnetic field in sub-telescopic structures with such very strong fields is found to be the same as in the background field, and the Doppler velocity is about 2 km/s (plasma lifting). Superstrong magnetic fields in the range of 5-5,7 kG were also detected from observations of the Big Bear Observatory (BBSO), USA. A unique observational material also obtained on AO KNU concerning the area of a seismic source of extremely powerful solar flare on October 28,2003 of X17.2 / $4 B$ class was analyzed. This solar flare had a Balmer decrement with a record intensity ratio I $(\mathrm{H} \beta) / \mathrm{I}(\mathrm{H \alpha})=1,68$ of the $\mathrm{H} \beta$ and $\mathrm{H \alpha}$ lines, which is unprecedented for all flares observed. In this flare, indications of the existence of particularly strong magnetic fields in the range of several tens of kilogauss were found. The semiempirical model of this flare has an interesting feature, namely three discrete layers with high plasma concentration and temperature, including a very thick and thin layer in the chromosphere with the following parameters: hydrogen concentration $n_{H}=10^{18} \mathrm{~cm}^{-3}$, thickness $\Delta \mathrm{h}=3-5 \mathrm{~km}$ and height $\mathrm{h} \approx 1200 \mathrm{~km}$ above the level of the photosphere. In active solar prominences, rather strong magnetic fields (up to $4 \mathrm{kG}$ ) were detected at altitudes of 3-14 Mm. The modeling of spectral line profiles within the two-component model showed that the true magnitude of local magnetic fields can be even greater by at least 3 times. A theoretical MHD model is proposed, according to which such high strengths occur in force-free magnetic ropes with a characteristic scale of 300 km.

Key words: Sun, solar activity, spectral-polarization observations, magnetic fields, thermodynamic conditions, solar faculae, spots, flares, prominences, semi-empirical models.

УдК 523.98

В. Криводубський, д-р фіз.-мат. наук Київський національний університет імені Тараса Шевченка, Київ

\section{ДОСЛІДЖЕННЯ ЦИКЛІЧНОСТІ МАГНЕТИЗМУ СОНЦЯ В МЕЖАХ TEOPIÏ MАКРОСКОПІЧНОї МАГНІТОГІДРОДИНАМІКИ}

Із середини 70-х рр. минулого століття в Астрономічній обсерваторії Київського національного університету імені Тараса Шевченка започатковано новий напрям теоретичних досліджень еволюції глобального магнетизму Сонця в межах макроскопічної МГД. У роботі наведено підсумки вивчення процесів генерації і перебудови великомаситабного (глобального) магнітного поля на основі моделі $\alpha \Omega$-динамо з урахуванням нових турбулентних ефектів, відкритих у теорії макроскопічної МГД, і даних геліосейсмологічних експериментів про внутрішнє обертання Сонця.

Установлено, що різкий радіальний градієнт турбулентної швидкості в нижній половині сонячної конвективної зони (СКЗ) приводить до зміни знаку азимутальної компоненти параметра спіральності $\alpha$, у результаті чого поблизу дна СК 3 відбувається формування відносно тонкого шару негативного $\alpha$-ефекту. Знайдено, що шар негативного $\alpha$-ефекту разом зі знаком радіального градієнта кутової швидкості, виявленим у геліосейсмологічних експериментах, дозволяє пояснити напрямок міграції динамо-хвиль на сонячній поверхні. Розраховано магнітне насичення $\alpha$-ефекту (альфа-квенчінг) у глибоких шарах СКЗ. Запропоновано пояснення затяжної тривалості 23-го сонячного циклу, яка становила близько 13 років. Для цього використано спостережені дані про суттєве зростання річного модуля магнітних полів сонячних плям у 23-му циклі. Розрахована північно-південна асиметрія структури глобального магнітного поля надає можливість пояснити феномен уявного магнітного "монополя", який спостерігається під час переполюсовок полярного магнетизму. Знайдено, що величини турбулентної електропровідності й турбулентної магнітної проникності сонячної плазми суттєво менші відповідних газокінетичних параметрів. Тому турбулентна дисипація сонячних магнітних полів підсилюється на 4-9 порядків величини порівняно із класичною омічною дисипацією. Досліджено макроскопічний турбулентний діамагнетизм сонячної плазми. Знайдено, що в нижній частині СКЗ турбулентний діамагнетизм діє проти магнітної плавучості, виконуючи таким чином роль "негативної магнітної плавучості". У результаті балансу ефектів магнітної плавучості й турбулентного діамагнетизму у глибинах СКЗ формується шар заблокованого магнітного поля величиною $\approx 3000$ Гс. Досліджено турбулентну адвекцію магнітного поля в неоднорідній за густиною плазмі СКЗ. Знайдено, що в нижній половині СКЗ приекваторіального домену турбулентна адвекція спрямована догори. У результаті сумісної дії магнітної плавучості й турбулентної адвекції глибинні сильні тороїдальні поля виносяться на поверхню Сонця в широтній "королівській зоні" сонячних плям. Відзначено роль горизонтального турбулентного діамагнетизму в забезпеченні тривалої стабільності сонячних плям. Для пояснення спостереженого явища подвійних максимумів циклу сонячних плям розроблено сценарій, що містить генерацію магнітного поля в тахокліні біля дна СКЗ і наступне винесення иього поля із глибинних шарів на поверхню в широтній "королівській зоні". Відзначено роль радіального омега-ефекту у променистій зоні в поясненні спостереженої асиметрії амплітуди двох сусідніх 11-річних циклів сонячних плям.

Ключові слова: турбулентність, макроскопічна магнітогідродинаміка, Сонце, глобальне магнітне поле, геліосейсмологія, $\alpha \Omega$-динамо, конвективна зона, магнітна плавучість, овершут, тахоклін, промениста зона, сонячні плями, 11-річний магнітний цикл.

Вступ. Однією з фундаментальних проблем сучасної геліогеофізики є питання про походження й варіації магнітної активності Сонця та її земні прояви. Із точки зору довгострокового прогнозування всього комплексу геліогеофізичних явищ особливої актуальності набуває потреба вивчення й обґрунтування циклічності глобального магнетизму Сонця. 3 огляду на це, виникає необхідність пошуку механізмів, які приводять до збудження магнетизму в сонячних надрах. Глобальне внутрішнє магнітне поле залучається дослідниками для пояснення низки спостережених фактів (дефіциту потоку сонячних нейтрино, тонка структура акустичних коливань Сонця, недостача вмісту літію в сонячній атмосфері та ін.). У статті викладено результати вивчення автором ефектів генерації й перебудови глобального маг- 
нітного поля Сонця, проведених у межах теорії макроскопічної магнітогідродинаміки (Мгд) на основі моделі турбулентного динамо з урахуванням останніх даних геліосейсмологічних експериментів про внутрішнє обертання Сонця.

Турбулентні ефекти макроскопічної мгД. Найбільшого поширення серед дослідників циклічності глобального магнетизму Сонця набули переконання, що спусковим механізмом циклу служить процес гідромагнітного (турбулентного) динамо. На сьогодні більшість деталізованих математичних моделей динамо ґрунтується на теорії усереднених (згладжених) полів [1], яка вивчає поведінку макроскопічних електромагнітних і гідродинамічних полів у турбулентній плазмі (так звана макроскопічна магнітогідродинаміка). У турбулентній плазмі всі фрізичні поля нерегулярно змінюються у просторі й часі. Для опису впливу турбулентності на властивості електропровідного середовища у всіх фізичних параметрів дослідники виділяють глобальні та флуктуаційні складові. Теорія макроскопічної МГД основана на двомасштабному підході до гідродинамічних рухів у замагніченій турбулентній плазмі, рівнянь Максвелла і закону Ома для густини електричного струму. Макроскопічна МГД набула широкого застосування при астрофізичних дослідженнях, оскільки в космічних умовах досить часто трапляється ситуація, коли поле швидкостей розділене на два суттєво відмінні просторові масштаби, саме так, як вимагає теорія усередненого поля. Зокрема, у конвективній зоні Сонця поле гідродинамічних рухів природно розділене на дві складові. Перша - глобальна складова - великомасштабна (регулярна) швидкість U, що відповідає сонячному обертанню. Iї̈ масштаб $L$ порівнянний із розмірами сонячної конвективної зони (СКЗ). Друга - флуктуаційна складова - маломасштабна турбулентна конвекція u, масштаб якої / значно менший $L$. Унаслідок вмороженості магнітного поля в сонячну плазму дрібний масштаб / властивий як для поля швидкості u, так і для магнітного поля b. Водночас глобальному магнітному полю В (див. нижче) також притаманний великий масштаб, порівнянний із розмірами Сонця. Для отримання макроскопічних електромагнітних параметрів турбулентної плазми дослідники здійснюють процедури усереднення (тобто згладження) фрізичних характеристик за просторовими (a) або часовими $(t)$ масштабами, які значно перевищують кореляційні масштаби довжини / або часу $\tau$ турбулентних пульсацій, але менші відповідних великомасштабних просторових $L$ або часових $T$ характеристик регулярних рухів $(I<<a<<L, \tau<<t<<T)$.

У межах теорії макроскопічної МГД було відкрито три нових ефекти впливу турбулентності на електродинамічні властивості замагніченої плазми [1,2]. Вплив фактора турбулентності проявляється у виникненні додаткового "турбулентного" електричного поля $\varepsilon=\langle\mathbf{u} \times \mathbf{b}\rangle / c$ у виразі закону Ома для усередненої (макроскопічної) густини електричного струму $\langle\mathbf{j}\rangle$ у рухомому середовищі

$$
\langle\mathbf{j}\rangle=\sigma\left\{\langle\mathbf{E}\rangle+\frac{1}{c}(\langle\mathbf{U}\rangle \times\langle\mathbf{B}\rangle)+\frac{1}{c}\langle\mathbf{u} \times \mathbf{b}\rangle\right\},
$$

де $\langle\mathbf{E}\rangle$ i $\langle\mathbf{B}\rangle$ - електричне і магнітне усереднені (великомасштабні) поля, $\langle\mathbf{U}\rangle$ - великомасштабна швидкість регулярних рухів, u i b - швидкість турбулентних пульсацій і маломасштабне магнітне поле, $\sigma$ - коефріцієнт електропровідності. Кутові дужки $\langle\ldots\rangle$ означають усереднення за масштабами і часовими проміжками, які значно перевищують масштаб i час кореляції турбулентних рухів. Вираз для усередненої "турбулентного" електричного поля $\varepsilon$ має вигляд [1, 2]

$$
\boldsymbol{\varepsilon}=\frac{1}{c}\langle\mathbf{u} \times \mathbf{b}\rangle=\varepsilon_{\text {gen }}+\boldsymbol{\varepsilon}_{\text {dif1 }}+\boldsymbol{\varepsilon}_{\text {dif2 }}=\frac{1}{c}\left\{\alpha\langle\mathbf{B}\rangle-\frac{1}{2} \nabla_{v_{T}} \times\langle\mathbf{B}\rangle-v_{T} \operatorname{rot}\langle\mathbf{B}\rangle\right\} .
$$

Ключову роль у теорії турбулентного динамо відіграє $\alpha$-ефект (перший член у правій частині рівняння (2), суть якого полягає в можливості збудження гіротропними турбулентними рухами $(<\mathbf{u} \cdot \operatorname{rot} \mathbf{u}>\neq 0)$ у замагніченій плазмі додаткового "турбулентного" електричного поля $\varepsilon$ gen $=\alpha\langle\mathbf{B}\rangle / c$, паралельного чи антипаралельного (залежно від знаку параметра усередненої гіротропності $\alpha=-(\tau / 3)<\mathbf{u} \cdot \operatorname{rot} \mathbf{u}>$ ) до великомасштабного поля $\langle\mathbf{B}\rangle$ (тут $v_{\mathrm{T}} \approx(1 / 3) u l-$ коефріцієнт турбулентної в'язкості, яка викликає дисипацію (загасання) магнітного поля; $u, l$ i $\tau$ - відповідно ефективна швидкість, характерний масштаб і час кореляції турбулентних пульсацій). Виникнення макроскопічного "турбулентного" електричного поля $\varepsilon$ gen, паралельного до напрямку усередненого магнітного поля $\langle\mathbf{B}\rangle$ у середовищі, яке в середньому $є$ нерухомим, але перебуває у стані турбулентних рухів, разюче суперечить звичній картині у класичній електродинаміці, коли індуковане регулярними рухами електричне поле завжди $є$ перпендикулярним до напрямку магнітного поля. Творці теорії макроскопічної МГД М. Штеєнбек (із Йєнського інституту магнітогідродинаміки), Ф. Краузе і К.-Х. Редлер (із Потсдамського інституту астрофізики) зазначений процес назвали " $\alpha$-ефектом" [1]. Незважаючи на свою довільність, цей термін досить міцно вкоренився в літературі, а сам $\alpha$-ефект є суттю всієї сучасної теорії турбулентного динамо. Хоча вперше (1955 р.) із фрізичних міркувань цей ефект виявив Е. Паркер (див. нижче) й евристично ввів параметр циклонічності Г, що майже збігається з уведеним пізніше параметром гіротропності $\alpha$. Згодом Г. Моффрат (1978 р.) запровадив термін спіральна (англ. helical) турбулентність [3], який нині став загальновживаним. Із додатковим турбулентним електричним полем пов'язане нове магнітне поле $\mathbf{B}_{1}\left(\operatorname{rot} \mathbf{B}_{1}=4 \pi \sigma \tau \varepsilon_{\text {gen }} / c^{2}\right)$, що забезпечує підсилення і тривале зберігання глобального магнетизму (бт - турбулентна електропровідність). За досить інтенсивної спіральної турбулентності в астрофрізичних об'єктах $\alpha$-ефект збуджує магнітні поля, які можуть протистояти омічним виснаженням електричних струмів, відкриваючи тим самим прямий шлях до пояснення походження космічного магнетизму.

Наступний важливий ефект макроскопічної МГД (який описується другим членом $\varepsilon_{\text {dif1 }}=-(\nabla v \mathrm{~T} / 2)\langle\mathbf{B}\rangle / c$ у правій частині рівняння (2)) полягає в тому, що в неоднорідному турбулентному середовищі можуть активізуватися кілька еволюційних змін макроскопічного магнітного поля, які прийнято називати турбулентною перебудовою великомасштабного магнітного поля [2].

Нарешті, третій ефект турбулентності полягає у зростанні турбулентної магнітної дифузії, яка значно перевищує омічну дисипацію струмів (третій член $\varepsilon_{\text {dif2 }}=-v_{\text {T }} \operatorname{rot}\langle\mathbf{B}\rangle / c$ у правій частині рівняння (2)). Забезпечуючи швидкі зміни, зокрема, загасання магнітних полів, турбулентна дифузія створює необхідність постійного збудження магнетизму.

Модель $\alpha \Omega$-динамо магнітного циклу Сонця. Згідно із сучасними уявленнями $[1,2]$ аксіально-симетричне глобальне магнітне поле Сонця В складається із двох компонент. Перша компонента - приховане від спостерігачів гли- 
бинне сильне тороїдальне (азимутальне) поле $\mathbf{B}_{T}$ (величиною $\geq 10^{3}$ Гс), фррагменти якого при спливанні проявляються на фотосферному рівні у вигляді локальних біполярних магнітних дуг, визначаючи тим самим інтенсивність плямоутворення. Друга компонента - слабке полоїдальне (меридіональне) поле Вр (із максимальною величиною 1-2 Гс), силові лінії якого, виходячи на сонячну поверхню, формують фонові магнітні поля, зокрема, полярні магнітні поля. Спостереження свідчать [2], що обидві компоненти осцилюють у часі і просторі із середнім періодом близько 11 років у протифазі. Тому очевидно, що ці компоненти пов'язані між собою, і збуджуються, напевне, одним процесом, який носить коливальний циклічний характер. Як уже зазначено, дослідники магнетизму Сонця вважають, що циклічність спостережених явищ сонячної магнітної активності забезпечується механізмом турбулентного динамо [1, 2].

Роль "динамо-машини" на Сонці відіграє його конвективна зона, де в результаті взаємодії великомасштабного обертання (із кутовою швидкістю $\Omega$ ) і маломасштабної конвекції (яка характеризується полем швидкостей и) створюється специфічна комбінація диференційного обертання і спіральної турбулентної конвекції. Під впливом обертання (коріолісової сили) в умовах сильного вертикального градієнта густини плазми турбулізовані конвективні рухи в підфотосферних шарах набувають анізотропного спірального характеру, тоді як унаслідок анізотропії конвекції обертання стає неоднорідним (диференційним) [1, 2].

Тороїдальне поле у принципі створити дуже просто. Диференційне обертання $\Omega(r, \theta)$ в умовах умороженості магнітних полів у високопровідну сонячну плазму розтягує силові лінії вихідного полоїдального поля $\mathbf{B}_{P}$ і тим самим генерує тороїдальну компоненту В $\Omega$-ефектом [1, 2]. Він описується першим членом правої частини рівняння індукції

$$
\partial \mathbf{B}_{T} / \partial t=r \sin \theta\left(\mathbf{B}_{P} \nabla\right) \boldsymbol{\Omega} \dot{i}_{\varphi}+v_{T} \Delta \mathbf{B}_{T},
$$

де $r$ - відстань від центра Сонця, $\nabla \equiv \partial / \partial r$ - радіальний градієнт, $\mathbf{i}_{\varphi}-$ азимутальний одиничний вектор, $\theta-$ полярний кут (коширота) у сореричній системі координат. Зауважимо, що тут і далі кутові дужки 〈...〉 для зручності математичного опису опущено, оскільки нижче ми будемо розглядати тільки глобальні (усереднені) параметри досліджуваних полів. Уперше індукційний ефект диференційного обертання в магнітному середовищі виявив М. Ельзассер ще 1946 р. при вивченні питання про походження земного магнетизму [4].

Каменем спотикання і найважливішою ланкою для дослідників тривалий час залишалася проблема зворотного зв'язку тороїдального поля з полоїдальним: як відтворити в наступному циклі полоїдальне поле, та ще і протилежного спрямування (протилежної магнітної полярності) щодо його орієнтації (полярності) в попередньому циклі. Допоки нарешті Ю. Паркер (1955р.) уперше запропонував механізм регенерації полоїдального поля із тороїдального поля внаслідок індукційного ефекту циклонічної турбулентності [5]. Магнітні силові лінії спливаючих фррагментів тороїдального поля в умовах умороженості під впливом циклонічної конвекції витягуються в магнітні петлі 3 ненульовою складовою в меридіональній площині. Зливаючись за рахунок дифузії, магнітні петлі відновлюють полоїдальне поле протилежної полярності. Після Паркера стало зрозуміло, що для підсилення магнітного поля і циклічних його змін особливо ефективною $є$ комбінація неоднорідного обертання й асиметричного поля маломасштабних швидкостей. Фізична концепція Паркера отримала математичне обґрунтування у циклі робіт (опублікованих в 60-х рр. минулого століття) творців макроскопічної МГД. Заслуга Штеєнбека, Краузе і Редлера полягає в тому, що вони виявили здатність спіральної турбулентності підсилювати первісне слабке поле. По суті, Ельзассер і Паркер мовою вморожених магнітних полів, конвективних комірок і спливаючих закручених магнітних петель запропонували якісну модель динамо, тоді як Штеєнбек, Краузе і Редлер дали математичний підхід до тих же процесів мовою процедур усереднення і кореляційних тензорів. Усереднена спіральна турбулентність $\alpha(r, \theta)$ регенерує із поля $\mathbf{B}_{T}$ нову полоїдальну компоненту $\mathbf{B}_{P}$, антипаралельного спрямування щодо його вихідної орієнтації ( $\alpha$-ефект), замикаючи тим самим досить просто сонячний динамо-цикл [1, 2]. Регенерація полоїдального поля описується першим членом правої частини рівняння

$$
\partial \mathbf{A} / \partial \mathrm{t}=\alpha \mathbf{B} T+\nu T \Delta \mathbf{A}
$$

де $\mathbf{A}=\mathbf{A} \mathbf{i}$ - тороїдальний векторний потенціал $\left(\mathbf{B}_{P}=\operatorname{rot} \mathbf{A}\right)$. Перші члени у правих частинах рівнянь (3) i (4) відповідають за збудження магнітних полів диференційним обертанням і $\alpha$-ефеектом, а другі - за турбулентне загасання полів. Турбулентна дифузія відіграє кілька важливих функцій: вона об'єднує маломасштабні магнітні петлі в одне згладжене поле, сприяє поширенню великомасштабного поля з області його генерації по всій СКЗ і, нарешті, найважливішим є те, що вона не допускає необмеженого зростання тороїдальної і полоїдальної компонент магнітного поля. Зауважимо, що обмеження на величину збуджених полів чинить також магнітна плавучість [5] (див. нижче).

Механічна енергія диференційного обертання і турбулентної конвекції служить джерелом постійного підживлення магнетизму Сонця в сучасну епоху, а відхилення від симетрії турбулентного поля спіральних швидкостей (дзеркально-несиметрична турбулентність) не допускає загасання динамо-процесу. У випадку, коли генерація і турбулентна дифрузія (другі члени праворуч у рівняннях (3) і (4)) магнітних потоків урівноважені, отримують циклічний механізм самопідтримання тороїдальної і полоїдальної компонент великомасштабного магнітного поля, який у літературі прийнято називати моделлю " $\alpha \Omega$-динамо" [1, 2].

Згідно з Ю. Паркером [5] розв'язок рівнянь $\alpha \Omega$-динамо (3) і (4) можна подати у вигляді динамо-хвиль, які при спостереженнях проявляються як хвилі магнітної активності, що мігрують у меридіональному напрямку від середніх широт до екватора. Період $T$ динамо-хвиль, який відповідає тривалості сонячного циклу, визначається величиною добутку параметрів спіральності $\alpha$ і радіального градієнта кутової швидкості $\partial \Omega / \partial r[5]$

$$
T \approx 2 \pi /\{(1 / 2)|\alpha \partial \Omega / \partial r|\}^{1 / 2}
$$

Х. Йошимура уточнив у [6], що напрямок меридіонального зміщення динамо-хвиль (до екватора чи полюса) залежить від знаку (від'ємного чи додатного) добутку $\alpha \partial \Omega / \partial r$.

Зазначимо ще одну проблему геліофізики. Тривалий час при вивченні сонячної циклічності на основі механізмів, в основу яких покладено базову модель $\alpha \Omega$-динамо, дослідники зустрічалися з певними труднощами, значною мірою 
пов'язаними з обмеженістю інформації про внутрішнє обертання Сонця, яку, до недавнього часу, вони отримували в основному внаслідок теоретичного моделювання. Принципово новий шлях до визначення глибинного диференційного обертання відкрили геліосейсмологічні експерименти [7], які на сьогодні служать надійним "інструментом" вивчення внутрішніх шарів Сонця.

Нижче наведено підсумки проведеного нами впродовж останніх 40 років вивчення процесів генерації і перебудови глобального магнітного поля Сонця на основі моделі $\alpha \Omega$-динамо з урахуванням нелінійних ефектів замагніченої турбулентної плазми, ефектів "негативної магнітної плавучості" макроскопічної МГД і останніх досягнень геліосейсмології у вивченні внутрішнього обертання Сонця.

Зміна знаку параметра спіральної турбулентності в СКЗ і напрямок міграції динамо-хвиль. Вплив обертання Сонця на турбулентність приводить до тензорного характеру $\alpha$-ефекту. Для сонячного $\alpha \Omega$-динамо найважливішою $€$ азимутальна компонента $\alpha$-едекту: $\alpha(r, \theta)=\alpha(r) \cos \theta$. Залежність від радіуса параметра $\alpha(r)$ кількісно описується виразом [1]:

$$
\alpha(r) \cong-\frac{\tau}{3}\langle\mathbf{u} \cdot \operatorname{rot} \mathbf{u}\rangle \cong-\frac{2}{3} \Omega l^{2} \nabla \ln (\rho u)=-\frac{2}{3} \Omega l^{2}\left(\frac{\nabla \rho}{\rho}+\frac{\nabla u}{u}\right)=\alpha^{\rho}(r)+\alpha^{u}(r),
$$

де $\alpha^{\rho} \cong-(2 / 3) \Omega I^{2}(\nabla \rho / \rho)$ і $\alpha^{u} \cong-(2 / 3) \Omega I^{2}(\nabla u / u)$ - відповідно складові параметра спіральності, зумовлені неоднорідністю густини речовини і неоднорідністю ефективної швидкості турбулентних пульсацій. Із наведеного виразу видно, що для існування у природі спіральних рухів поле турбулентних швидкостей мусить мати принаймні два переважні напрямки: $\nabla \ln (\rho u)$ і $\Omega$. 3 огляду на це ясно, що спіральність $€$ абсолютно природним ефектом, який завжди з необхідністю виникає під впливом коріолісової сили, стратифікації густини речовини та неоднорідності поля швидкостей у всіх геофізичних і астрофрізичних турбулізованих системах, що обертаються і перебувають у полі гравітації, зокрема, у конвективних зонах небесних тіл [1, 2].

Нами проаналізовано поведінку параметра $\alpha(r)$ в СКЗ. При обчисленнях використано фрізичні параметри СКЗ із моделі М. Стікса [8]. Ураховано протилежні за знаком внески в $\alpha$-ефект, зумовлені радіальними градієнтами густини плазми $(\nabla \rho / \rho)$ і швидкості турбулентних пульсацій $(\nabla u / u)$ [9-12]. У результаті встановлено, що в більшій частині об'єму СКЗ переважаючий внесок у величину параметра $\alpha$ дає вертикальна стратифікація речовини $\nabla \rho$ (додатна за знаком складова $\alpha^{\rho}$ ). Проте в ділянках поблизу дна конвективної зони, де інтенсивність турбулентної конвекції різко спадає до нуля, більш вагомим стає внесок, зумовлений вертикальною неоднорідністю пульсацій речовини $\nabla u$ (від'ємна за знаком складова $\alpha^{u}$ ), що приводить тут до зміни знаку (із додатного на від'ємний) сумарного параметра спіральності $\alpha(r)$. Відповідно до цього, параметр $\alpha(r, \theta)=\alpha(r) \cos \theta$ змінює свій знак із додатного на від'ємний у північній півкулі та 3 додатного на від'ємний у південній півкулі. У результаті поблизу дна СКЗ у північній півкулі формується відносно тонкий шар від'ємного $\alpha$-ефекту $(\alpha<0)$, в якому максимальне від'ємне значення параметра $\alpha$ становить $\approx-7 \cdot 10^{3}$ см/с. Виявлена нами зміна знаку параметра спіральності $\alpha$ має принципове значення для пояснення спостереженої меридіональної міграції поверхневих магнітних полів. Згідно з даними геліосейсмологічних експериментів [7] радіальний градієнт кутової швидкості в низькоширотному домені СКЗ має додатний знак $(\partial \Omega / \partial r>0)$. 3 огляду на це добуток $\alpha \cdot \partial \Omega / \partial r<0$ задовольняє умову Х. Йошимури [6], необхідну для зміщення динамо-хвиль до екватора, яке при спостереженнях упродовж циклу проявляється у вигляді меридіональної міграції сонячних плям (закон Шпьорера). Разом із тим, на високих широтах $\left(\theta^{*}>50^{\circ}\right.$, позначення $\theta^{*}=90^{\circ}-\theta$ означає геліошироту), де $\partial \Omega / \partial r<0$ [7], динамо-хвилі мігрують до полюсів. Очевидно, ці хвилі відповідальні за спостережний полярний дрейфр слабких великомасштабних (фонових) магнітних полів.

Магнітний альфа-квенчінг у глибоких шарах СКз. Зростаюче магнітне поле в нелінійному режимі уповільнює процеси самозбудження магнетизму, насамперед, пригнічує $\alpha$-ефект, як найбільш упорядкований, чутливий і слабший порівняно із $\Omega$-ефектом. Уплив магнітного поля на $\alpha$-7ефект можна описати виразом $\alpha(\beta)=\alpha_{0} \Psi_{\alpha}(\beta)$, де $\alpha_{0}$ - "немагнітне" значення параметра спіральності, $\Psi_{\alpha}(\beta)$ - функція магнітного пригнічення $\alpha$-ефекту (так звана квенчінг-функція, нормалізована на одиницю при $\beta=0$ [13]), $\beta=B / B_{e q}$ - параметр нормалізованого магнітного поля, $B_{\text {eq }} \approx u(4 \pi \rho)^{1 / 2}$ - рівнорозподілена магнітна індукція, яка збуджується маломасштабними турбулентними пульсаціями $u$. При зростанні магнітного поля величина квенчінг-фрункції зменшується (в асимптотичному наближенні прямує до нуля), таким чином зупиняючи подальше збудження магнетизму, у чому й полягає фізична суть магнітного альфа-квенчінгу.

Нами було вивчено магнітне насичення параметра турбулентної спіральності у глибоких шарах СКЗ, де завдяки ефектам негативної магнітної плавучості виявляються заблокованими сильні магнітні поля $B s \approx 3000 \div 4000$ Гс (див. нижче наші розрахунки). Установлено [9-12,14], що величина квенчінг-функції $\Psi_{\alpha}(\beta s)$ поблизу дна СКЗ становить близько $0,3 \div 0,4$, у результаті чого магнітне пригнічення веде до зменшення від'ємного значення параметра спіральності до величини $\alpha(\beta \mathrm{s})=\alpha_{0} \Psi_{\alpha}(\beta \mathrm{s}) \approx-3 \cdot 10^{3} \mathrm{~cm} / \mathrm{c}$. Зменшення величини параметра спіральності сприяє подовженню розрахованого періоду динамо-циклу (див. нижче).

Затяжна тривалість 23-го сонячного циклу. У межах моделі $\alpha \Omega$-динамо нами запропоновано пояснення подовженої тривалості 23-го сонячного циклу, яка становила близько 13 років. Для цього ми використали спостережені дані 23-го циклу про суттєве зростання річного модуля магнітних полів сонячних плям $B_{s p}$ [15], який характеризує інтенсивність спливаючого глибинного тороїдального поля. Було розраховано магнітне пригнічення $\alpha$-ефекту, пов'язане зі спостереженим зростанням параметра $B_{s p}$. Квенчінг-функція і параметр спіральності для сильного магнітного поля, характерного для плям, набувають вигляду: $\Psi_{\alpha}\left(B_{s p}\right)=15 \pi / 64 B_{s p}{ }^{3}, \alpha\left(B_{s p}\right)=\alpha_{0} 15 \pi / 64 B_{s p}{ }^{3}$ [13]. Оскільки період динамо-циклу пропорційний величині $\alpha^{-1 / 2}$ (див. вираз (5)), то він залежить від магнітного поля таким чином: $T \sim \alpha^{-1 / 2} \sim B_{s p} 3 / 2$. Тобто, чим сильніше магнітне поле сонячних плям, тим довшою має бути тривалість динамо-циклу. Згідно з даними спостережень $[15,16]$ магнітний параметр $B_{s p}$ у максимумі 23-го циклу зріс приблизно в 1,13 раз порівняно з його значенням в епоху мінімуму. Відповідно до цього розрахована нами величина функції магнітного насичення $\Psi_{\alpha}\left(B_{s p}\right) \sim B_{s p}{ }^{-3}$ в максимумі циклу зменшилася в 1,44 раз і становила $\approx 0,7$ її значення в мінімумі. Тому такою ж мірою 
в максимумі циклу також був меншим (сильніше магнітно пригніченим) і параметр спіральності ( $\left.\alpha \sim \Psi_{\alpha}\right)$. Зважаючи на це, розрахований динамо-період 23-го циклу $T \sim \alpha^{-1 / 2} \sim B_{s p}^{3 / 2}$ мусить збільшитися в $(0,7)^{-1 / 2} \approx(1,13)^{3 / 2} \approx 1,2$ раз (порівняно 3 його середнім значенням $\approx 11$ років) і становити близько 13 років $[17,18]$ відповідно до спостережень.

Феномен магнітного "монополя" Сонця. Магнітографічні спостереження навколополярних магнітних структур свідчать про те, що в більшості випадків полоїдальне поле можна описати диполем, антисиметричним щодо екваторіальної площини. Разом із тим, упродовж п'яти останніх циклів реверсація північного і південного полярних полів в епохи сонячних максимумів відбувалася з інтервалом $1 \div 2$ роки. У результаті обидва магнітні полюси в ці епохи мали однаковий знак. Спостережена магнітна асиметрія започаткувала дискусію по проблемі так званого магнітного "монополя" Сонця. Щоб пояснити феномен згаданого магнітного "монополя" дослідники допускають, що в цей час на Сонці домінувала магнітно-симетрична відносно екватора квадрупольна гармоніка полоїдального поля (див., наприклад, [19]). Теорія динамо зобов'язана обґрунтувати справедливість припущення щодо можливого співіснування двох основних магнітних гармонік (диполя і квадруполя) і домінування квадрупольної моди в конфігурації полоїдального поля в максимумі циклу.

У моделі $\alpha \Omega$-динамо пороги збудження дипольної і квадрупольної гармонік є досить близькими і відрізняються тільки знаком критичного динамо-числа К $\lambda=\left[(\alpha \partial \Omega / \partial r)\left(\lambda^{3} / v^{2}\right)\right]^{1 / 3}$, тут $\lambda$ - меридіональна протяжність ділянки генерації [5]. Зважаючи на це, конфігурація магнітного поля в СКЗ суттєво залежить від знаків параметра турбулентної спіральності $\alpha$ і радіального градієнта кутової швидкості $\partial \Omega / \partial r$. Згідно з нашими розрахунками (див. вище) у нижній частині СКЗ, де відбувається збудження глобального поля, параметр спіральності набуває від'ємного знаку ( $\alpha<0)$ [9-12]. Разом із тим, за даними геліосейсмологічних експериментів [20] СКЗ поділена на домени із протилежними знаками параметра $\partial \Omega / \partial r$. У низькоширотному домені $\left(\theta^{*}=0^{\circ} \div 40^{\circ}\right) \partial \Omega / \partial r$ має від'ємний знак, тоді як у високоширотних доменах $\left(\theta^{*}=50^{\circ} \div 90^{\circ}\right) \partial \Omega / \partial r$ характеризується додатним знаком. Врахувавши це, ми обчислили динамо-числа окремо для низькоширотного і високоширотних доменів генерації [11,21]. У низькоширотному домені (де $\partial \Omega / \partial r>0, \alpha<0)$ розрахована величина динамо-числа становить $\kappa_{1} \lambda_{1} \approx-7$, яка близька до критичного за Паркером значення К $\lambda=-7,43$, необхідного для генерації диполя [5]. Водночас у високоширотних доменах $(\partial \Omega / \partial r<0, \alpha<0)$ розрахований параметр $К_{2} \lambda_{2} \approx+8$ виявився близьким до критичного динамо-числа К $\lambda=+7,43$, необхідного для збудження квадруполя. 3 огляду на це, низькоширотний домен служить джерелом збудження першого типу змішаної парності (симетричності) динамо-гармонік, в якому домінуючу роль відіграє антисиметричний відносно екватора диполь. Тоді як у спектрі магнітних гармонік, що збуджуються у високоширотних доменах, переважає квадруполь - другий тип змішаної парності динамо-гармонік. Таким чином, якщо врахувати виявлений геліосейсмологією природний поділ СКЗ на домени з різними режимами внутрішнього обертання $[7,20]$, то $\alpha \Omega$-процес у глибинних шарах приводить до збудження двох типів змішаної магнітної парності динамо-гармонік. Домінуючі гармоніки кожного типу відіграють свою певну роль у сценарії магнітного циклу. Упродовж більшого часу циклом править диполь, який несе відповідальність за північно-південне співвідношення знаків магнітних полюсів глобального поля, що описується законом Хейла. Проте при наближенні до моменту зміни знаку (реверсації) полярного магнетизму створюються сприятливі умови для збудження квадруполя на фоні загасаючого диполя. На результуючій картині розподілу поверхневого магнетизму, яка відповідає цій конфігурації, навколополюсні зони матимуть однаковий знак, нагадуючи монополь. Таким чином, розрахована нами північно-південна магнітна асиметрія [10, 21] надає можливість пояснити феномен уявного магнітного "монополя", який спостерігається під час переполюсовок полярного магнетизму.

Спіральна негативна турбулентна дифузія і фрагментація магнітних полів. Спостереження засвідчують дивну властивість поверхневих магнітних полів на Сонці проявлятися у вигляді широко рознесених дискретних магнітних силових трубок (МСТ) однакової полярності. Тому необхідно зрозуміти, як можуть виникати уніполярні магнітні структури, незважаючи на взаємне відштовхування полів однієї полярності. 3 урахуванням енергетичних міркувань прийнято вважати, що спостережувані на сонячній поверхні ізольовані МСТ є результатом магнітного спливання на поверхню сильних полів із сонячних глибин. 3 огляду на це, необхідно дослідити фізичні процеси у глибинних шарах, що призводять до дискретної структури магнітних полів Сонця.

На основі числового моделювання Р. Крейчнан [22] показав, що маломасштабна турбулентна дифузія з урахуванням спіральних рухів може сприяти фрагментації неперервних магнітних полів у дискретні структури (синергетичний перехід до сильної неврівноваженості процесу). Виявлена ним тенденція турбулізованих спіральних рухів відповідає властивостям негативної турбулентної в'язкості, фрізична суть якої полягає в передачі енергії спіральних турбулентних пульсацій від малих масштабів до великих (так званий зворотний каскад перенесення енергії). Ключовим параметром нового явища служить час існування усереднених спіральних вихорів $\langle\mathbf{u} \cdot \operatorname{rot} \mathbf{u}$, який має бути більшим характерного часу життя самих комірок. За такої умови стійка турбулентна спіральність має дивну властивість "стягувати" присутні магнітні поля, а не розсіювати їх (маломасштабний $\alpha^{2}$-ефект спіральної негативної турбулентної магнітної дифузії) [22].

Нами проведено розрахунки для двох моделей СКЗ, які показали, що у глибинних шарах існують сприятливі умови для збудження ефекту спіральної негативної турбулентної дифузії [23]. У припущенні, що час існування спіральних структур збігається за величиною із часом життя конвективних комірок, було знайдено, що розраховані значення коефіцієнта спіральної негативної магнітної турбулентної дифузії досягають 2/3 величини коефіцієнта додатної турбулентної дифузії. Тому маломасштабний $\alpha^{2}$-ефект у глибинних шарах СКЗ може суттєво сприяти самоорганізації слабких неперервних магнітних полів у дискретні МСТ. Спливаючи на сонячну поверхню, очевидно саме ці дискретні поля фрормують спостережену структуру магнетизму, в якій співіснують ізольовані МСТ у широкому діапазоні розмірів полів (від пор до сонячних плям).

Турбулентна магнітна дифузія. Один із важливих ефектів турбулентності полягає в аномальному зниженні величин коефіцієнтів електропровідності й магнітної проникності плазми, що призводить до суттєвого зменшення часу релаксації магнітних процесів. Ефект впливу турбулентної електропровідності та турбулентної магнітної проникності на швидкість еволюційної зміни згладженого магнітного поля В зумовлюється додатковим дифузійним "турбулент- 
ним" електричним полем $\varepsilon_{\text {dif2 }}=-v_{T} \operatorname{rot} B / c$ (третій член у правій частині рівняння (2)). Кількісно параметри турбулент-

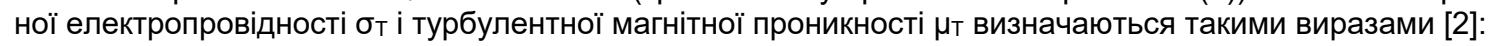

$$
\sigma_{\mathrm{T}}=\sigma /\left(1+v_{\mathrm{T}} / v_{m}\right)^{1 / 2}, \quad \mu_{\mathrm{T}}=1 /\left(1+v_{\mathrm{T}} / v_{m}\right)^{1 / 2},
$$

де $\sigma$ - звичайна газокінетична електропровідність плазми, $v_{m}=c^{2} / 4 \pi \sigma-$ магнітна в'язкість.

Для фрізичних характеристик плазми в конвективній зоні, узятих із моделі СКЗ [8], зазвичай виконується умова $v_{T} / v_{m}>>1$. 3 огляду на це коефріцієнти турбулентної провідності й магнітної проникності набувають вигляду: $\sigma_{T} \approx \sigma /\left(v_{T} / v_{m}\right)^{1 / 2}$, $\mu_{\mathrm{T}} \approx 1 /\left(v_{\mathrm{T}} / \mathrm{vm}^{1 / 2}\right.$. Згідно з нашими розрахунками величина турбулентної провідності в СКЗ (бт $\left.\approx 1 \cdot 10^{9} \div 4 \cdot 10^{11} \mathrm{CГCЕ}\right)$ виявилася значно меншою за величину газокінетичної електропровідності ( $\sigma \approx 1 \cdot 10^{11} \div 4 \cdot 10^{16} \mathrm{CГCЕ),} \mathrm{тоді} \mathrm{як} \mathrm{величина} \mathrm{турбулент-}$ ної магнітної проникності $\mu_{\mathrm{T}} \approx 10^{-2} \div 10^{-5} \mathrm{CГCE}-$ значно меншою газокінетичної магнітної проникності, яка дорівнює одиниці [24]. За такої умови коефіцієнт турбулентної магнітної дифузії $D_{\top}=v_{T}+v_{m}=c^{2} / 4$ то $\sigma_{T} \mu_{\text {т }}$ суттєво перевищує коефіцієнт газокінетичної магнітної в'язкості $v_{m}=c^{2} / 4 \pi \sigma$. Зважаючи на це, ефективна дисипація сонячних магнітних полів з урахуванням турбулентності підсилюється на 4-9 порядків величини порівняно із класичною омічною дисипацією. У результаті характерний час турбулентного перенесення тороїдального поля з області його генерації біля дна СКЗ до сонячної поверхні стає порівнянним із тривалістю циклу. Крім того, надзвичайно актуально те, що турбулентна дифузія, яка веде до швидкого знищення (загасання) полів, створює необхідність постійної ефективної генерації магнітного поля. Водночас вона необхідна для контролю над необмеженим зростанням магнітного поля в турбулентному середовищі.

Необхідність пошуку ефектів "антиплавучості". Для ефективного збудження тороїдального поля в результаті дії диференційного обертання на полоїдальне поле необхідно, щоб магнітні силові трубки тривалий час перебували в ділянці генерації. Проте внаслідок магнітної плавучості Е. Паркера [5] важко забезпечити значне підсилення і зберігання сильних полів в усьому об'ємі СКЗ упродовж тривалого часу. Швидкість магнітного спливання поля В за Паркером визначається виразом

$$
\mathrm{U}_{\mathrm{B}}(\mathrm{B}, \rho) \approx \mathrm{B} /(4 \pi \rho)^{1 / 2}
$$

із якого видно, що величина швидкості спливання обернено пропорційна густині плазми $\rho$, що призводить до обмеження на амплітуду збуджуваного тороїдального поля. 3 огляду на це, найбільш сприятливі умови для утримання сильних магнітних полів у сонячних глибинах існують біля дна СКЗ, де найбільша густина плазми. I тому саме тут буде найменшою швидкість магнітного спливання. Але навіть біля дна СКЗ важко забезпечити підсилення й утримання полів, величиною більше 100 Гс, упродовж часу, порівнянного з періодом сонячного циклу (через швидку евакуацію сильних магнітних полів із зони генерації) [5]. Тому з особливою потребою на перший план виступає проблема компенсації магнітної плавучості сильних полів й утримання їх упродовж тривалого часу в ділянці динамо. Зважаючи на це, виникає актуальна необхідність пошуку механізмів магнітної "антиплавучості" ("негативної магнітної плавучості"). Як виявилося, роль таких механізмів у СКЗ можуть виконувати турбулентні ефекти макроскопічної МГД: турбулентний діамагнетизм і магнітна адвекція в неоднорідній за густиною турбулентній плазмі.

Макроскопічний турбулентний діамагнетизм сонячної плазми. Перейдемо до розгляду ефекту турбулентної перебудови магнетизму, який описується другим членом у правій частині рівняння (2). Видно, що вплив додаткового дифузійного "турбулентного" електричного поля $\varepsilon_{\text {dif1 }}=-(\nabla v \mathrm{~T} / 2)$ B/c на згладжене магнітне поле В еквівалентний дії постійного поля швидкостей

$$
\mathbf{U}_{\mu}=-\nabla v_{\mathrm{T}} / 2
$$

Тобто згладжене магнітне поле В переноситься через турбулентне середовище зі швидкістю $-\nabla v \mathrm{v} / 2$, хоча ніякого усередненого руху плазми не існує. Ефект був відкритий Я. Зельдовичем для випадку двовимірної турбулентності [25] і пізніше К-Х. Редлером названий макроскопічним турбулентним діамагнетизмом [26]. Фізичний сенс останнього полягає у витісненні однорідного в початковий момент магнітного поля з ділянок високопровідної плазми з підвищеною інтенсивністю турбулентних рухів у місця з менш розвиненою турбулентністю (уздовж градієнта турбулентної в'язкості $\left.\nabla v_{T}\right)$ з ефрективною швидкістю $U_{\mu}$.

Саме таким чином проявляється макроскопічний турбулентний діамагнетизм у конвективній зоні Сонця. У результаті проведених нами розрахунків $[11,27]$ установлено, що радіальний профіль турбулентної в'язкості $v \mathrm{~T}(\mathrm{z}) \approx(1 / 3) u l$ має вигляд випуклої функції з максимумом $v т \approx 10^{13} \mathrm{~cm} / \mathrm{c}$ у нижній половині СКЗ. Виявлена вертикальна неоднорідність параметра $v$ т вказує на діамагнітні властивості сонячної турбулізованої плазми. Актуально те, що в нижній частині СКЗ, де величина vт турбулентної в'язкості різко зменшується із глибиною z, турбулентний діамагнетизм, очевидно, мусить діяти проти магнітної плавучості. Дійсно, згідно з нашими розрахунками, швидкість спрямованого донизу діамагнітного витіснення горизонтального поля поблизу дна СКЗ досягає значень $U_{\mu} \approx 2 \cdot 10^{3} \mathrm{~cm} / \mathrm{c}$. Оскільки швидкість магнітного спливання залежить від величини поля $B$, то з умови взаємної компенсації процесів спливання зі швидкістю $\bigcup_{B}$ (див. вираз (8)) і діамагнітного витіснення донизу зі швидкістю $U_{\mu}$ (вираз (9)) можна знайти значення стаціонарного тороїдального поля $B_{0} \approx U_{\mu}(4 \pi \rho)^{1 / 2}$, спливання якого буде повністю компенсовано макроскопічним турбулентним діамагнетизмом. Наші розрахунки показали [11,27], що в результаті балансу двох зазначених ефектів у глибинах СКЗ формується магнітний шар товщиною 40 тис. км із величиною заблокованого тороїдального магнітного поля $\approx 3000$ Гс.

Отже, помітне зменшення турбулентної швидкості при наближенні до дна СКЗ зумовлює спрямоване донизу інтенсивне діамагнітне витіснення поля, яке сприяє тривалому утриманню тороїдального поля у зоні генерації. Таким чином, макроскопічний турбулентний діамагнетизм у нижній частині СКЗ, діючи проти магнітної плавучості, виконує роль "негативної магнітної плавучості", необхідної для компенсації швидкого спливання сильних полів із ділянок генерації.

Турбулентна адвекція тороїдального магнітного поля. У турбулентному середовищі поряд із макроскопічним діамагнетизмом за певних умов може збуджуватися ще один ефект макроскопічної перебудови магнетизму. Фізична суть його така. У неоднорідній за густиною $\rho$ турбулентній плазмі маломасштабні магнітні пульсації b призводять до зміни просторового розподілу великомасштабного магнітного поля В, яке можна представити як перенесення (адве- 
кцію) цього поля вздовж градієнта густини плазми $\nabla \rho$ [28]. У нелінійному режимі цей просторовий перерозподіл поля еквівалентний його перенесенню в напрямку зростання густини плазми. За умови рівнорозподілу густини кінетичної енергії $\rho u^{2} / 2$ і густини магнітної енергії маломасштабних пульсацій $b^{2} / 8 \pi$ вираз для швидкості перенесення великомасштабного поля В набуває вигляду [29]

$$
\mathbf{U}_{\rho}=(1 / 6) \tau b^{2} \nabla \rho / 4 \pi \rho \approx(1 / 6) \tau u^{2} \nabla \rho / \rho .
$$

Для зазначення тієї обставини, що причиною описаного ефекту турбулентної адвекції є градієнт густини плазми, ми назвали його $\nabla \rho$-ефектом $[11,30]$. Нині ми запроваджуємо термін $\nabla \rho$-адвекція магнітного потоку, який, на нашу думку, краще відповідає фрізичній суті процесу перенесення магнітного поля в неоднорідній турбулентній плазмі.

Величина густини плазми при заглибленні в конвективну зону Сонця зростає вздовж радіуса приблизно на 5-6 порядків величини [8]. 3 огляду на це, слід очікувати, що в СКЗ виникатиме ще один ефект "негативної магнітної плавучості" - спрямований донизу магнітний потік (адвекція), зумовлений радіальним градієнтом густини плазми. Дійсно, у результаті проведених нами розрахунків згідно з виразом (10) знайдено, що у глибинних шарах СКЗ швидкість спрямованої донизу $\nabla \rho$-адвекції магнітного потоку досягає значень $U_{\rho} \approx 10^{2} \div 10^{3} \mathrm{~cm} / \mathrm{c}[11,30]$. Виявлена нами радіальна $\nabla \rho$-адвекція, діючи проти магнітної плавучості, дає порівнянний із турбулентним діамагнетизмом внесок у фрормування поблизу дна СКЗ магнітного шару з величиною стаціонарного тороїдального поля $B_{0} \approx 3000$ Гс.

Обертання Сонця породжує анізотропію конвекції, яка наділяє $\nabla \rho$-адвекцію новими властивостями [31]. Ротаційний $\nabla \rho$-ефект здійснює "селекцію полів", у результаті чого тороїдальна й полоїдальна магнітні компоненти переносяться у радіальному і меридіональному напрямках незалежно. Найбільшої актуальності набуває вивчення радіального $\nabla \rho$-потоку тороїдального поля $\mathbf{B}_{T}$, оскільки вихід останнього на сонячну поверхню приводить до формування плям. Напрямок і швидкість радіальної $\nabla \rho$-адвекції поля В (кошироти) $\theta$, глибини $z$ і числа Коріоліса $\omega=2 \tau \Omega$ в СКЗ:

$$
\mathbf{U}_{\rho r} r^{T}(z, \theta, \omega)=6 \mathbf{U}_{\rho}(z)\left\{\varphi_{2}[\omega(z)]-\varphi_{1}[\omega(z)] \sin ^{2} \theta\right\} .
$$

Функції числа Коріоліса $\varphi_{1}[\omega(z)]$ і $\varphi_{2}[\omega(z)]$ описують вплив обертання на турбулентну конвекцію. Залежно від знаку множника $\left\{\varphi_{2}[\omega(z)]-\varphi_{1}[\omega(z)] \sin ^{2} \theta\right\}$ магнітний потік може бути спрямованим як донизу (коли цей знак додатний), так $\mathrm{i}$ догори (коли знак множника від'ємний). Тому слід очікувати досить складної широтно-радіальної залежності $\mathbf{U}_{\rho r}{ }^{\top}(z, \theta, \omega)$ в СКЗ.

У результаті проведених нами розрахунків $\mathbf{U}_{\rho r}{ }^{\top}(z, \theta, \omega)$ було знайдено $[11,32]$, що у високоширотних ділянках $\left(\theta^{*}>45^{\circ}\right)$ радіальна $\nabla \rho$-адвекція тороїдального поля у всьому об'ємі СКЗ спрямована донизу, тоді як у приекваторіальному домені $\left(\theta^{*}<45^{\circ}\right)$ напрямок магнітного потоку залежить від вертикальної локалізації полів (рис. 1). У поверхневих шарах в умовах повільного обертання $(\omega \approx 0,01 \div 0,5) \nabla \rho$-адвекція протидіє плавучості. Разом із тим, у нижній половині приекваторіального домену - де умови відповідають швидкому обертанню $(\omega \approx 5 \div 20)-$ нами ви-

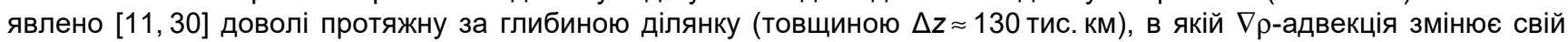
напрямок на протилежний - догори $\left(U_{\rho r}{ }^{T} \approx(1 \div 3) \cdot 10^{2} \mathrm{~cm} / \mathrm{c}\right)$. Унаслідок цього тут $\nabla \rho$-адвекція допомагає паркерівській

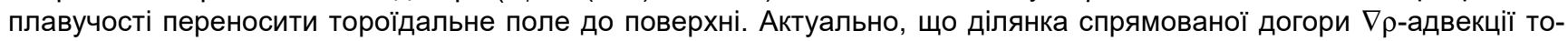
роїдального поля зосереджена в ділянці геліоширот від $45^{\circ}$ до екватора, яка збігається зі спостереженою широтною "королівською смугою" сонячних плям.

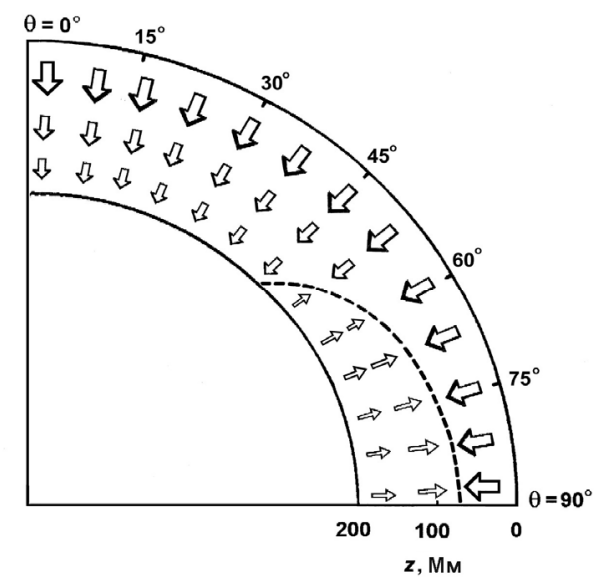

Рис. 1. Меридіональний розріз СКЗ, який демонструє розподіл радіальної швидкості $\nabla \rho$-адвекції тороїдального магнітного поля $U_{\rho r}{ }^{\top}(z, \theta, \omega)$ за глибиною $z$ (радіусом $r$ ) і коширотою (полярним кутом) $\theta$ [11]. Стрілочки показують напрямок перенесення. Штрихова крива відповідає лінії нульової швидкості $U_{\rho r}{ }^{\top}(z, \theta, \omega)=0$, де відбувається зміна напрямку радіального перенесення поля. Видно, що в більшій частині СКЗ спрямоване донизу перенесення протидіє класичній магнітній плавучості Паркера (тобто виконує роль механізму "антиплавучості").

Однак, у глибоких шарах у приекваторіальному домені (у діапазоні геліоширот $\theta^{*} \approx 0 \div 45^{\circ}$ біля дна СКЗ) його роль змінюється: магнітний потік, викликаний $\nabla \rho$-адвекцією, стає спрямованим, подібно до класичної магнітної плавучості, догори.

У результаті, тут радіальна $\nabla \rho$-адвекція допомагає паркерівському магнітному спливанню, що сприяє прориву сильних полів до поверхні, де вони з'являються як сонячні плями в широтній "королівській зоні" 
Роль горизонтального турбулентного діамагнетизму в забезпеченні тривалої стабільності плям. Як відомо із спостережень, магнітні поля на поверхні Сонця виявляють незвичну властивість спонтанно концентруватися в широко рознесені ізольовані МСТ у вигляді сонячних плям. Виникає питання, як пояснити тривалу стабільність рівноважного стану плями після спливання полів на поверхню, коли МСТ у підфотосферних шарах займають близьке до вертикального положення.

У зв'язку із зазначеною проблемою ми дослідили роль турбулентного діамагнетизму в забезпеченні рівноважного стану вертикальних МСТ [33]. Ідея полягає в тому, що сильне магнітне поле плями пригнічує інтенсивність турбулентних рухів у ній, тоді як поза межами плями, де магнітне пригнічення відсутнє, інтенсивність турбулентної конвекції буде більшою. У результаті, між цими ділянками мусить формуватися відносно тонкий своєрідний interface - вертикальний шар проникної конвекції, в якому інтенсивність турбулентної конвекції суттєво зменшується в поперечному напрямку при переході від фотосфери/СКЗ до плями. Тому в зазначеному перехідному шарі створюються сприятливі умови для поперечного (горизонтального) макроскопічного діамагнетизму, який може впливати на перебудову магнітного поля плями. Унаслідок відмінностей величини турбулентних пульсацій у перехідному вертикальному шарі проникної конвекції виникає ефект турбулентного діамагнітного витіснення поля із фотосфери/СКЗ до плями. Інтенсивні турбулентні пульсації в СКЗ будуть повертати назад до плями магнітне поле, яке завдяки процесу турбулентної дифузії намагається просочуватися у протилежному напрямку - зовні плями. Тобто тут має місце конкуренція двох протилежно спрямованих процесів перенесення магнітного поля в горизонтальній площині. Під впливом сильної зовнішньої турбулентності пограничні магнітні поля, які внаслідок турбулентної дифузії просочуються із плями у фротосфреру/СКЗ, будуть "закидатися" назад у пляму. Саме цей ефект, на наш погляд [33], може сприяти тривалому утриманню плям у вигляді ізольованих вертикальних МСТ.

Шар проникної конвекції (овершут) поблизу дна СКз. Оскільки при заглибленні у сонячні надра зменшується паркерівська швидкість магнітного спливання, то при вивченні процесів збудження і перебудови глобального магнетизму увагу дослідників привертають глибинні шари СКЗ. Найбільш привабливими виглядають найглибші шари: перехідна ділянка (interface) між конвективною і променистою зонами, де характерні розміри поля швидкостей зазнають кардинальної перебудови. Суть процесів у перехідній ділянці така. Як уже зазначалося, поля швидкостей у СКЗ природно розділені на два масштаби: маломасштабну турбулентну конвекцію $u(r, \theta)$ і великомасштабне диференційне обертання $\Omega(r, \theta)$. Характерні розміри цих двох полів швидкостей достатньо великі для того, щоб між СКЗ і променистою зоною виникали ділянки поступового спадання амплітуди швидкостей. Тому біля дна СКЗ мусять сформуватися два перехідні шари різних масштабів, в яких відбувається перебудова поля швидкостей. Перший шар, який пов'язаний із перебудовою турбулентної конвекції, у літературі отримав назву шар проникної конвекції або конвективний овершут (англ. convective overshoot layer) [34]. Саме в шарі конвективного овершуту турбулентні механізми "негативної магнітної плавучості" ефективно компенсують магнітну плавучість Паркера (див. нижче). У підсумку, конвективний овершут служить резервуаром тривалого утримання тороїдального поля, яке завдяки механізмам "антиплавучості" проникає сюди з об'єму СКЗ. Незважаючи на привабливість шару проникної конвекції для перебудови магнетизму, він, імовірно, занадто тонкий. Тому конвективний овершут не може суттєво впливати на збудження магнітного поля, а тільки, як уже зазначено, сприяє тривалому збереженню поля. 3 огляду на це, особливого значення для перебудови магнетизму набуває другий перехідний шар, який простягається в надра Сонця глибше СКЗ [35].

Глибинний шар перебудови диференційного обертання (тахоклін). Фізична суть тахокліну така. Згідно з геліосейсмологічними вимірюваннями [36] диференційне обертання проникає в радіативні надра (променисту зону), унаслідок чого на нижній межі СКЗ утворюється перехідний шар від широтного диференційного до твердотільного (жорсткого) обертання. Смуга різкого спадання кутової швидкості знаходиться нижче СКЗ, подібно до того, як термокліни лежать нижче шару перемішаної води в океані. Зважаючи на це, по аналогії з океанічним термокліном, перехідний шар спадання кутової швидкості Е. Шпігель і Ж.-П. Цан [35] назвали тахокліном (англ. tachocline), тобто шаром стрімкого спадання швидкості диференційного обертання. Товщина його за геліосейсмологічними вимірюваннями $\approx 30$ тис. км. Унаслідок різкого спадання кутової швидкості саме в тахокліні радіальний градієнт кутової швидкості досягає свого максимуму, чим створює тут найсприятливіші умови для збудження сильного тороїдального поля.

Таким чином, найбільш сприятливим місцем для генерації тороїдального магнітного поля служать глибинні шари поблизу дна СКЗ, що охоплюють шар проникної конвекції (овершут) і тахоклін. В овершуті створюються необхідні умови для формування шару тривалого утримання магнітних полів, тоді як у тахокліні внаслідок різкого спадання кутової швидкості ефрективно генерується потужне тороїдальне поле. Паркерівська плавучість останнього із часом переважає ефекти антиплавучості, в результаті чого воно виноситься на поверхню. Крім того, у глибинах СКЗ густина кінетичної енергії диференційного обертання значно перевищує густину магнітної енергії, що сприяє трансформації кінетичної енергії в магнітну. Важливим чинником глибинних шарів служить спрямована до екватору меридіональна течія, яка в межах моделі гідромагнітного динамо забезпечує міграцію тороїдальних полів від високих широт до низьких.

Подвійні максимуми циклу сонячних плям. Для пояснення спостереженого явища подвійних максимумів циклу сонячних плям нами розроблено сценарій [37], що містить генерацію тороїдального магнітного поля поблизу дна СКЗ і його наступне винесення із глибинних шарів на поверхню в геліоширотній "королівській зоні". У запропонованій схемі перебудови тороїдального магнітного поля беруть участь п'ять МГД-процесів: радіальний $\Omega$-ефект поблизу

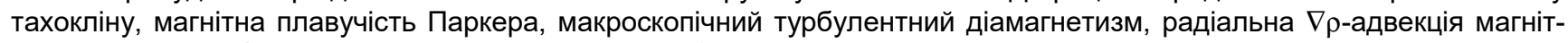
ного потоку і глибинна меридіональна циркуляція. Згідно із цим сценарієм в тахокліні внаслідок різкого радіального спадання кутової швидкості зі слабкого полоїдального поля ефективно генерується тороїдальне поле. У шарі конвективного овершуту два ефекти "негативної магнітної плавучості" (макроскопічний турбулентний діамагнетизм і радіальна $\nabla \rho$-адвекція) упродовж певного часу компенсують паркерівське спливання тороїдального поля (поки це поле ще відносно слабке). Таким чином, конвективний овершут виконує роль сховища, де збуджене $\Omega$-ефектом тороїдальне поле може утримуватися тривалий час доти, поки воно не досягне значень $\approx 3000$ Гс [38]. 
Однак подальша перебудова заблокованого глибинного тороїдального поля у навколополярних і приекваторіальному доменах відбувається в різних режимах. Це пов'язано з тим, що у нижній частині приекваторіального до-

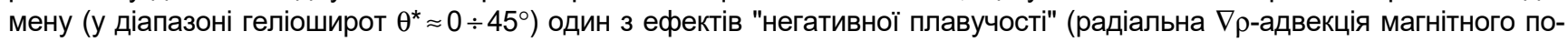
току), змінює свій знак, як зазначалося вище (див. рис. 1), на протилежний і стає спрямованим догори, допомагаючи тим самим паркерівській магнітній плавучості. Із часом, коли за рахунок $\Omega$-ефекту заблоковане у глибинах приекваторіального домену тороїдальне поле досягає величин > 3000 Гс, два спрямовані догори магнітні потоки (зумовлені комбінованою дією плавучості Паркера і $\nabla \rho$-адвекції) починають переважати спрямовану донизу "негативну магнітну плавучість", пов'язану з макроскопічним турбулентним діамагнетизмом. У міру подальшого підсилення тороїдального поля активізується його підйом до поверхні Сонця. Зрештою, через деякий час тороїдальне поле з'являється на поверхні у вигляді сонячних плям в ділянці "королівської геліоширотної зони". Ця спрямована догори перша хвиля тороїдальних полів відповідальна за основний максимум активності плямоутворення (рис. 2).

Разом із тим, у високоширотних полярних доменах під впливом двох ефектів "негативної плавучості" (турбулентного діамагнетизму і радіальної $\nabla \rho$-адвекції) глибинні тороїдальні поля впродовж усього циклу залишаються заблокованими в шарі конвективного овершуту. Саме тому поблизу полюсів ніколи не з'являються сонячні плями.

Вагому роль у подальшій еволюції заблокованих тороїдальних полів відіграє глибинна меридіональна циркуляція, яка забезпечує перенесення цих полів із полярних областей до низьких широт. Спрямована до екватора глибинна меридіональна течія витісняє заблоковані поблизу полюсів поля в низькоширотні ділянки, де існують сприятливі умови для спливання полів, оскільки тут спрямована догори радіальна $\nabla \rho$-адвекція допомагає плавучості переносити тороїдальне поле до поверхні. Якщо для швидкості глибинної меридіональної течії біля дна СКЗ $\left(\mathrm{r} \approx 5 \cdot 10^{10} \mathrm{~cm}\right)$ взяти величину $U_{M}^{(d e e p)} \approx 3 \div 5 \mathrm{M} / \mathrm{c}[20]$, то характерний час міграції поля від високоширотної ділянки $\theta_{1}^{*}=70^{\circ}$ до ділянки низьких геліоширот $\theta_{2}{ }^{*}=15 \div 20^{\circ}$ (смуги спостережуваного повторного збільшення кількості плям у максимумі циклу) становить $\tau_{M} \approx \mathrm{r}\left(\Delta \theta^{*} / 360^{\circ}\right) / \mathrm{U}_{\mathrm{M}}(\mathrm{deep}) \approx 1 \div 2$ роки. У низькоширотних ділянках ці мігруючі до екватора "запізнілі" поля згідно з описаною вище схемою транспортуються до поверхні, але вже на нижчих геліоширотах "королівської зони". Прориваючись на поверхню ця друга порція спливання затриманих у часі тороїдальних полів веде до повторного максимуму сонячних плям.
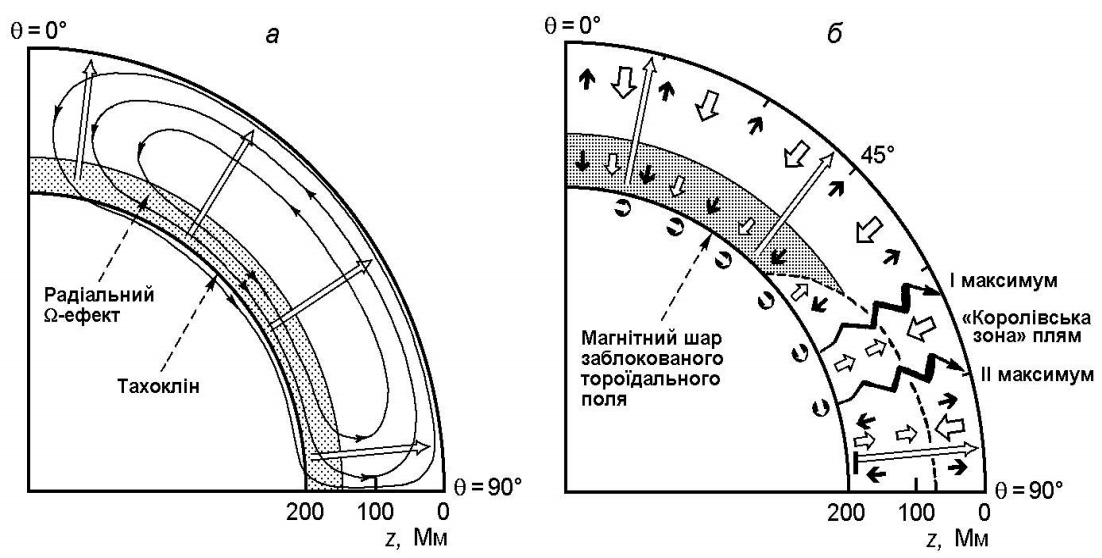

Рис. 2. Схема турбулентної перебудови тороїдального магнітного поля в СКЗ [37]:

а - меридіональна циркуляція (овальні замкнуті чорні стрілки); магнітна плавучість (спрямовані до поверхні світлі стрілки); шар радіального $\Omega$-ефекту (заштрихована ділянка) поблизу дна СКЗ; б - (ə) перенесення із високоширотних областей до приекваторіального домену заблокованого біля полюсів глибинного тороїдального поля (заштрихована ділянка)

унаслідок глибинної меридіональної течії; - ר - спрямовані до поверхні хвилі тороїдального поля, зумовлені перевагою двох спрямованих догори магнітних потоків: плавучості Паркера (довгі світлі стрілки) і $\nabla \rho$-адвекції (короткі білі стрілки) над спрямованим донизу ефектом "негативної магнітної плавучості", пов'язаним із макроскопічним турбулентним діамагнетизмом (короткі чорні стрілки). Прориваючись на поверхню, дві хвилі тороїдального поля викликають у геліоширотній "королівській зоні" зсунуті в часі на 1-2 роки перший і другий максимуми сонячних плям

Таким чином, ключову роль у розробленому механізмі подвійних максимумів плям відіграють дві спрямовані догори хвилі тороїдальних полів, що поширюються у приекваторіальному домені від нижньої основи СКЗ до сонячної поверхні, і які завдяки глибинній меридіональній циркуляції зсунуті одна від одної в часі на 1-2 роки [37].

Радіальний омега-ефект у променистій зоні та чергування амплітуди сонячних циклів. Останнім часом особливої актуальності набуває питання пошуку механізмів, які приводять до збудження магнетизму в сонячних надрах нижче СКЗ, оскільки потужне внутрішнє магнітне поле залучається дослідниками для пояснення низки спостережених фрактів (дефіцит потоку сонячних нейтрино, тонка структура акустичних коливань Сонця, недостача вмісту літію в сонячній атмосфері та ін.). В результаті геліосейсмологічних експериментів було встановлено, що в надрах Сонця глибше конвективної зони і тахокліну впродовж тривалого часу може зберігатися помітний радіальний граді-

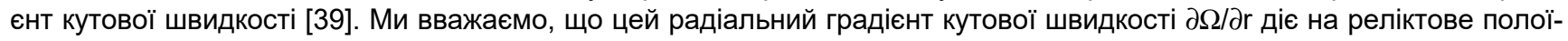
дальне поле, збуджуючи тим самим (унаслідок $\Omega$-ефекту) тороїдальне магнітне поле у променистій зоні нижче СКз. 3 огляду на це, нами проведено аналіз процесів генерації і втрати магнітного потоку (унаслідок плавучості Паркера [5]) у стабільній променистій зоні $[11,40]$. 3 умови балансу зазначених процесів виведено формулу для оцінювання максимального значення стаціонарного тороїдального поля сталого спрямування, яке збуджується радіальним $\Omega$-ефектом за наявності глибинного полоїдального поля реліктового походження і може утримуватися у променистій зоні доти, доки завдяки магнітній плавучості воно не буде винесено із зони генерації вгору в СКз: 


$$
\max \left|B_{\phi}\right| \equiv B_{\phi}^{\circ}=O\left(\left[\frac{\Gamma}{\gamma_{\mathrm{b}}}\right]^{1 / 3}\right)=O\left(\left[G B_{r} \frac{8 \pi P L}{u_{\mathrm{T}}}\left(\frac{a}{\lambda_{\mathrm{T}}}\right)^{2}\right]^{1 / 3}\right)
$$

Тут позначено: $\Gamma \equiv G B_{\mathrm{r}}$ і $\gamma_{\mathrm{b}} \equiv\left(u_{\mathrm{T}} / 8 \pi P L\right)(\lambda \mathrm{T} / \mathrm{a})^{2}$ - параметри, що характеризують відповідно швидкість збудження магнітного потоку диференційним обертанням і швидкість втрати магнітного потоку внаслідок плавучості у променистій зоні; $G \equiv r . \partial \Omega / \partial r$ - міра радіального диференційного обертання на відстані $r$ від центра Сонця;

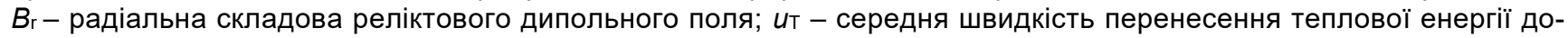
гори; $\lambda_{\mathrm{T}}$ - температурна шкала висот; $P$ - газовий тиск; $L$ - характерний масштаб зміни поля; а - поперечний радіус магнітної силової трубки. Якщо взяти до уваги інтенсивність реліктового радіального поля поблизу ядра Сонця $B_{\mathrm{r}} \approx 0,1 \div 10$ Гс, то визначений із геліосейсмологічних експериментів [39] радіальний градієнт кутової швидкості у променистій зоні $\left(\partial \Omega / \partial \mathrm{r} \approx 8 \cdot 10^{-18}\right.$ рад/с.см) здатний згенерувати досить сильне глибинне тороїдальне магнітне поле $B_{\phi}^{\circ}$ постійного спрямування. Поблизу сонячного ядра величина поля може досягати значень $\approx 10^{6}$ Гс, тоді як на верхній межі променистої зони становитиме $\approx 10^{4}$ Гс $[11,40]$. Ми вважаємо, що це тороїдальне магнітне поле сталого спрямування в часі, проникаючи завдяки магнітній плавучості із променистої зони в СКЗ вторгається тут у циклічний $\alpha \Omega$-процес і викликає тим самим спостережену магнітну асиметрію інтенсивності двох сусідніх 11-річних циклів [41].

Висновок. У роботі подано результати вивчення в Астрономічній обсерваторії університету процесів генерації і перебудови глобального магнітного поля Сонця в межах теорії турбулентного динамо усередненого поля. Наведений у статті перелік відтворених спостережених фрактів сонячної активності свідчить про те, що модель $\alpha \Omega$-динамо з урахуванням турбулентних ефектів макроскопічної МГД і новітніх даних геліосейсмологічних експериментів про внутрішнє обертання Сонця досить адекватно описує динаміку сонячного магнітного циклу і відображає реальні процеси, які мають місце в сонячній конвективній зоні. Отримані результати дослідження циклічності глобального магнетизму Сонця можуть бути корисними при вивченні механізмів сонячно-земних зв'язків і розробці методів аналізу і прогнозування всього комплексу геліо-геофізичних процесів, оскільки великомасштабні магнітні структури, що виносяться сонячним вітром у міжпланетний простір, насамперед, визначають умови в геліосфері, навколоземному космічному просторі, магнітосфері, іоносфері, і значною мірою впливають на атмосферу, гідросферу, літосферу й біосферу Землі.

\section{Список використаних джерел}

1. Krause F. Mean Field Magnetohydrodynamics and Dynamo Theory / F. Krause, K.-H. Rädler. - Oxford : Pergamon Press, Ltd. - 1980. - 271 p.

2. Вайнштейн С.И. Турбулентное динамо в астрофизике / С.И. Вайнштейн, Я.Б. Зельдович, А.А. Рузмайкин. - М. : Наука. - 1980. - 352 с.

3. Moffatt H.K. Magnetic Field Generation in Electrically Conducting Fluids / H.K. Moffatt. - London-New York-Melbourne : Cambridge University Press, 1978.

4. Elsasser W.M. Induction effects in terrestrial magnetism / W.M. Elsasser // Phys. Rev. - 1946. - 69. - P. $106-116$.

5. Parker E.N. Cosmical Magnetic Fields / E.N. Parker. - Oxford : Clarendon Press, 1979.

6. Yoshimura H. Solar-cycle dynamo wave propagation / H. Yoshimura // Astrophys. J. - 1975 - 201, No 3. - P. 740-748.

7. Christensen-Dalsgaard J. Helioseismology / J. Christensen-Dalsgaard // Rev. Mod. Phys. - 2002. - 74. - P.1073-1129.

8. Stix M. The Sun / M. Stix. - Berlin-Heidelberg-New York : Springer-Verlag. - 1989. - P. 200.

9. Krivodubskij V.N. Intensity of sources of magnetic fields of the solar $\alpha \omega$-dynamo / V.N. Krivodubskij // Soviet Astronomy. - 1984. - 28, No. 3. - P. 316-320.

10. Krivodubskij V.N. Rotational anisotropy and magnetic quenching of gyrotropic turbulence in the solar convective zone / V.N. Krivodubskij // Astronomy Reports. - 1998. - 42, No. 1. - P.122-126.

11. Krivodubskij V.N. Turbulent dynamo near tachocline and reconstruction of azimuthal magnetic field in the solar convection zone / V.N. Krivodubskij // Astron. Nachrichten. - 2005. - 326, No. 1. - P. 61-74.

12. Krivodubskij V.N. Dynamo parameters of the solar convection zone / V.N. Krivodubskij // Kinematics Phys. Celestial Bodies. - 2006. - 22, No. 1. - P. 1-20.

13. Rüdiger G. Alpha-effect and alpha-quenching / G. Rüdiger, L.L. Kitchatinov // Astron. Astrophys. - 1993. - Vol. 269. - P. 581-588.

14. Krivodubskij V.N. Alpha-quenching in the solar convection zone / V.N. Krivodubskij // Изв. Крым. астрофиз. обс. - 1998. - 94. - C. 180-184

15. Лозицкая Н. И. Сравнение результатов визуальных измерений магнитных полей крупных солнечных пятен, выполненных в разных обсерваториях в 23 цикле солнечной активности / Н.И. Лозицкая, Г.В. Лямова, В.М. Малащук // Изв. Крым. астрофиз. обс. - 2007. - 103, № 4. - С. 59-67.

16. Krivodubskij V.N. Dependence of solar cycle duration on the magnitude of the annual module of the sunspots magnetic field / V.N. Krivodubskij, N.I. Lozitska // Solar and Astrophysical Dynamos and Magnetic Activity. Proc. IAU Symp. No. 294, 2012; A.G. Kosovichev, E.M. de Gouveia Dal Pino, Y.Yan, eds. -2013 - P. $71-72$.

17. Krivodubskij V.N. On the extended 23rd solar cycle / V.N. Krivodubskij, O.K. Cheremnykh // Kosmichna Nauka i Tekhnolohija. - 2011. - 17, No. 1. P. 23-28 (In Russian).

18. Krivodubskij V.N. On the extended 23rd solar cycle / V.N. Krivodubskij // Solar and Astrophysical Dynamos and Magnetic Activity. Proc. IAU Symp. No. 294, 2012; A.G. Kosovichev, E.M. de Gouveia Dal Pino, Y. Yan, eds. - 2013. - P. 69-70.

19. Howard R. Studies of solar magnetic fields. I. The average field strengths / R. Howard // Solar Phys. - 1974. - 38. - P. 283-299.

20. Dynamic variations at the base of the solar convection zone / R. Howe, J. Christensen-Dalsgaard, F. Hill et al. // Science. - 2000. - 287. - P. 2456-2460.

21. Krivodubskij V.N. The structure of the global solar magnetic field excited by the turbulent dynamo mechanism / V.N. Krivodubskij // Astronomy Reports. -

2001. - 45, No. 9. - P. 738-745.

22. Kraichnan R.H. Diffusion of passive-scalar and magnetic fields by helical turbulence / R.H. Kraichnan // J. Fluid Mech. - 1976. - 77. - P. 753-774

23. Krivodubskij V.N. Small-scale alpha-squared effect in the solar convection zone / V.N. Krivodubskij // Kinematics Phys. Celestial Bodies. - 2015. - 31, No. 2. - P. 55-64.

24. Krivodubskij V.N. On turbulent conductivity and magnetic permeability of solar plasma / V.N. Krivodubskij // Soln. dannyje [Solar data]. - 1982. - № 7. P. 99-109 (In Russian).

25. Зельдович Я.Б. Магнитное поле при двумерном движении проводящей жидкости / Я.Б. Зельдович // ЖЭТФ. - 1956. - Т. 31. - С. 154-156.

26. Rädler K.-H. Zur Elektrodynamik turbulent bewegterm leitender Mediem / K.-H. Rädler // Thesis. - 1966. - Univ. Jena.

27. Krivodubskij V.N. Magnetic field transfer in the turbulent envelope of the Sun / V.N. Krivodubskij // Soviet Astronomy. - 1984. - 28, No. 2. - P. 205-211.

28. Вайнштейн С.И. Магнитные поля в космосе / С.И. Вайнштейн. - М. : Наука. - 1983. - 240 с.

29. Кичатинов Л.Л. О магнитной гидродинамике средних полей в неоднородной турбулентной среде / Л.Л. Кичатинов // Магнит. гидродинамика. 1982. - № 3. - C. 67-73.

30. Krivodubskij V.N. Transfer of large-scale solar magnetic field by inhomogeneity of the material density in the convection zone / V.N. Krivodubskij // Soviet Astronomy Lett. - 1987. - 13, No. 9. - P. 338-341.

31. Kitchatinov L.L. Turbulent transport of magnetic fields in a highly conducting rotating fluid and the solar cycle / L.L. Kitchatinov // Astron. Astrophys. 1991. - 243, No. 2. - P. 483-491.

32. Krivodubskij V.N. Turbulent transport of large-scale magnetic field in the rotating solar convective zone / V.N. Krivodubskij // Soviet Astronomy. - 1992. 36, No. 4. - P.432-435. 
33. Krivodubskij V.N. Turbulent effects of sunspot magnetic field reconstruction / V.N. Krivodubskij // Kinematics Phys. Celestial Bodies. - 2012. - 28, No. 5. - P. 232-238.

34. Roxburgh I.W. Convection and solar structure / I.W. Roxburgh // Astron. Astrophys. - 1978. - 65. - P. 281-285.

35. Spiegel E.A. The solar tachocline / E.A. Spiegel, J.-P. Zahn // Astron. Astrophys. - 1992. - 265. - P. 106-114

36. Basu S. A study of possible temporal and latitudinal variations in the properties of the solar tachocline / S. Basu, H.M. Antia // MNRAS. - 2001. - 324. - P. 498-508.

37. Krivodubskij V.N. Double Maxima of 11-Year Solar Cycles / V.N. Krivodubskij // Kinematics Phys. Celestial Bodies. - 2017. - 33, No. 1. - P. 24-38.

38. Krivodubskij V.N. The role of the convective zone in the excitation of the magnetic activity of the Sun / V.N. Krivodubskij // Bulletin of Taras Shevchenko National University of Kyiv. Astronomy. - 2018. - No. 57. - P. 31-41.

39. Howe R. Solar interior rotation and its variation / R. Howe // Living Rev. Solar Phys. - 2009. - 6. - P. 1-75.

40. Dudorov A.E. The internal large-scale magnetic field of the Sun / A.E. Dudorov, V.N. Krivodubskij, T.V. Ruzmaikina, A.A. Ruzmaikin // Soviet Astronomy. - 1989. 33, No. 4. - P. 420-426.

41. Криводубський B.H. Збудження стаціонарного тороїдального поля в променистій зоні і чергування амплітуди сонячних циклів / V.N. Кrivodubskij // Astronomy and Space Physics in the Kyiv University. - Book of Abstracts. - International Conference. - May 28-May 31, 2019. - Kyiv, Ukraine. - P. 78-79.

Надійшла до редколегії 05.02.20

В. Криводубский, д-р физ.-мат. наук

Киевский национальный университет имени Тараса Шевченко, Киев

\section{ИССЛЕДОВАНИЕ ЦИКЛИЧНОСТИ МАГНЕТИЗМА СОЛНЦА В РАМКАХ ТЕОРИИ МАКРОСКОПИЧЕСКОЙ МАГНИТОГИДРОДИНАМИКИ}

С середины 70-х г2. прошлого века в Астрономической обсерватории Киевского национального университета имени Тараса Шевченко начато новое направление теоретических исследований эволюции глобального магнетизма Солнца в рамках макроскопической МГД. В работе приведены результаты изучения процессов генерации и перестройки крупномаситабного (глобального) магнитного поля на основе модели $\alpha \Omega$-динамо с учетом новых турбулентных эффектов, открытых в теории макроскопической МГД, и данных гелиосейсмологических экспериментов о внутреннем вращении Солнца.

Установлено, что резкий радиальный градиент турбулентной скорости в нижней половине солнечной конвективной зоны (СКз) приводит к изменению знака азимутальной компоненты параметра спиральности $\alpha$, в результате чего вблизи дна Скз происходит формирование относительно тонкого слоя отрицательного $\alpha$-эффекта. Найдено, что слой отрицательного $\alpha$-эффекта вместе со знаком радиального градиента угловой скорости, обнаруженного в гелиосейсмологических экспериментах, позволяет объяснить направление миграции динамо-волн на солнечной поверхности. Рассчитано магнитное насыщение $\alpha$-эффекта (альфа-квенчинг) в глубоких слоях СКЗ. Предложено объяснение затяжной продолжительности 23-го солнечного цикла, составляющей около 13 лет. Для этого были использованы наблюдаемые данные о существенном росте годового модуля магнитных полей солнечных пятен в 23-м цикле. Рассчитанная северо-южная асимметрия структуры глобального магнитного поля позволяет объяснить феномен кажущегося магнитного "монополя", который наблюдается во время переполюсовок полярного магнетизма. Найдено, что величины турбулентной электропроводности и турбулентной магнитной проницаемости солнечной плазмы существенно меньще соответствующих газокинетических параметров. Поэтому турбулентная диссипация солнечных магнитных полей усиливается на 4-9 порядков величины по сравнению с классической омической диссипацией. Исследован макроскопический турбулентный диамагнетизм солнечной плазмы. Найдено, что в нижней части СКЗ турбулентный диамагнетизм действует против магнитной плавучести, выполняя, таким образом, роль "отрицательной магнитной плавучести". В результате баланса эффектов магнитной плавучести и турбулентного диамагнетизма в глубинах СКЗ формируется слой заблокированного магнитного поля величиной $\approx 3000$ Гс. Исследована турбулентная адвекция магнитного поля в неоднородной по плотности плазме СКЗ. Найдено, что в нижней половине СКЗ приэкваториального домена турбулентная адвекция направлена вверх. В результате совместного действия магнитной плавучести и турбулентной адвекции глубинные сильные тороидальные поля выносятся на поверхность Солнца в широтной "королевской зоне" солнечных пятен. Отмечена роль горизонтального турбулентного диамагнетизма в обеспечении длительной стабильности солнечных пятен. Для объяснения наблюдаемого явления двойных максимумов цикла солнечных пятен разработан сценарий, содержащий генерацию магнитного поля в тахоклине у дна СКЗ и последующий вынос этого поля из глубинных слоев на поверхность в широтной "королевской зоне". Отмечена роль радиального омега-эффекта в лучистой зоне в объяснении наблюдаемой асимметрии амплитуды двух соседних 11-летних циклов солнечных пятен.

Ключевые слова: турбулентность, макроскопическая магнитогидродинамика, Солнце, глобальное магнитное поле, гелиосейсмология, $\alpha \Omega$-динамо, конвективная зона, магнитная плавучесть, овершут, тахоклин, лучистая зона, солнечные пятна, 11-летний магнитный цикл.

V. Krivodubskij, Dr Hab.

Taras Shevchenko National University of Kyiv, Kyiv

\section{STUDY OF MAGNETISM CYCLICITY OF THE SUN}

\section{IN THE FRAMEWORK OF THE MACROSCOPIC MAGNETOHYDRODYNAMICS THEORY}

Since the mid-70s of the last century, a new direction in theoretical studies of the evolution of the global magnetism of the Sun in the framework of macroscopic MHD has been launched at the Astronomical Observatory of the Taras Shevchenko National University of Kyiv. The paper presents the results of a study of the processes of generation and restructuring of a large-scale (global) magnetic field based on the $\alpha \Omega$-dynamo model, taking into account new turbulent effects discovered in the theory of macroscopic MHD and data of helioseismological experiments on the internal rotation of the Sun.

It was established that a sharp radial gradient of turbulent velocity in the lower half of the solar convective zone (SCZ) leads to a change in the sign of the azimuthal component of the helicity parameter $\alpha$, resulting in the formation of a relatively thin layer of negative $\alpha$-effect near the bottom of the SCZ. It was found that the layer of negative $\alpha$-effect, together with the sign of the radial gradient of the angular velocity, detected in helioseismological experiments, makes it possible to explain the direction of migration of dynamo-waves on the solar surface. The magnetic saturation of the $\alpha$-effect (alpha-quenching) in the deep layers of the SCZ was calculated. An explanation of the protracted duration of the 23 rd solar cycle of about 13 years is proposed. For this, we used the observed data on a significant increase of the annual module of the magnetic fields of sunspots in the 23rd cycle. The calculated north-south asymmetry of the structure of the global magnetic field provides an opportunity to explain the phenomenon of the seeming magnetic "monopole", which is observed during reversal of polar magnetism. It was found that the values of turbulent electrical conductivity and turbulent magnetic permeability of the solar plasma are significantly less than the corresponding gas-kinetic parameters. Therefore, the turbulent dissipation of solar magnetic fields is enhanced by 4-9 orders of magnitude compared with classical ohmic dissipation. Macroscopic turbulent diamagnetism of solar plasma was investigated. It has been found that in the lower part of the SCZ, turbulent diamagnetism acts against magnetic buoyancy, thus fulfilling the role of "negative magnetic buoyancy". As a result of the balance of the effects of magnetic buoyancy and turbulent diamagnetism, a layer of blocked magnetic field of magnitude $\approx 3000 \mathrm{G}$ is formed in the depths of the SCZ. The turbulent advection of a magnetic field in an inhomogeneous plasma density of the SCZ was studied. It was found that in the lower half of the SCZ of the equatorial domain, turbulent advection is directed upwards. As a result of the combined action of magnetic buoyancy and turbulent advection, deep strong toroidal fields are carried to the surface of the Sun in the latitudinal "royal zone" of sunspots. The role of horizontal turbulent diamagnetism in ensuring the long-term stability of sunspots was noted. To explain the observed phenomenon of double maxima of the solar spot cycle, a scenario was developed containing the generation of a magnetic field in the tachocline at the bottom of the SCZ and subsequent removal of this magnetic field from the depth layers to the surface in the latitudinal "royal zone". The role of the radial omega-effect in the radiant zone in explaining the observed asymmetry in the amplitude of two neighbouring 11-years sunspot cycles was noted.

Keywords: turbulence, macroscopic magnetohydrodynamics, the Sun, global magnetic fieldf, helioseismology, $\alpha \Omega$-dynamo, convection zone, magnetic buoyancy, overshoot, tachocline, radiant zone, sunspots, 11-year magnetic cycle. 